\title{
Presentation by Ernest Petrič
}

\section{Some Remarks on Future Challenges for the International Law Commission}

\author{
Member of the International Law Commission
}

While celebrating 70 years of work of the International Law Commission and discussing its contemporary work, its problems and its future, it is important to say a few words concerning its past. It is not necessary to speak of the past achievements of the Commission, which are generally considered a great contribution to the development of international law, in terms of codification and progressive development, but also by enhancing awareness and understanding of international law. It is however worthwhile to mention that, when 70 years ago the Commission was established and its statute was adopted, ${ }^{1}$ the world was a different place. International law was at that time to a large extent customary, not codified and not written international law, and, compared to nowadays, limited in its scope. Important branches of contemporary international law, like human rights law and environmental law - to mention just a few - did not yet exist or were only emerging as international law de lege ferenda. Thus, now, in a much different world and globalised international community, the Commission, whose statute, role and functioning has remained stable and has not much changed all those 70 years, should indeed be exposed to a critical review, in spite of its great past achievements.

The victorious powers after the Second World War, while establishing the new world order and the United Nations as its institutional core, could not overlook the expectations and hopes of people throughout the world, that international relations in the future should be ruled by international law and that the international community should be a community based on collective security and cooperation regulated by international law. The ideals of the greatest thinkers of the past, that the international community should be the community of peace and of rule of law, were to become reality.

At that time, international law was to a large extent of a customary nature, with all the characteristics and challenges of customary law. Among them, in particular, is the problem of legal certainty, the problem of determining whether a norm exists and what its precise meaning, its substance, is. In other words, for customary international law - as for any customary law - the problem of "lex certa" was,

1 Statute of the ILC, UNGA Res 174(II) (21 November 1947). 
and still is, crucial, since customary international law is not written law, unless it is codified in an international treaty. After 1945, and when in 1948 the Commission was established, most international law, with the exception of bilateral treaties and laws of war (jus in bello) and some other multilateral arrangements, was customary international law. There was no codified international law even on matters crucially important for regulating communications and relations among States, such as diplomatic and consular law and the law of treaties. Codification, and in its context progressive development of international law, was a must for international relations to function. Besides, many new spheres and matters of international cooperation appeared which had to be regulated by international law. Moreover, in the ideologically divided, bipolar international community during the Cold War, several legal concepts were not commonly shared. They were interpreted differently, reflecting different sets of values. To clarify the existing and binding international law, the codification was a great necessity.

Thus, the role of the Commission, as a subsidiary organ of the General Assembly of the United Nations for the codification and progressive development of international law, was exceptionally important and useful to States. Consequently, its work has attracted great attention of States, expressed in the General Assembly and its Sixth Committee. The work of the Commission was considered crucial for closing the gaps in international law and to clarify the uncertainties of its interpretation. With some simplification, it could be said that the most important parts of international law have been codified - partially also progressively developed - in the first four decades of existence and work of the Commission. It was the time of the Commission's greatest achievements in assisting States to codify and progressively develop international law, as some say, the "golden age" of the Commission. It was also the time of high interest of States for the Commission's work, which was also reflected in the respect and recognition given to the Commission and its members, whose status at that time could be compared to the International Court of Justice and its judges. However, those times have passed.

I will now turn to my contribution to the panel's discussion on the Commission's future. Due to the limited time and scope, I will not be able to consider all specific contemporary problems of the Commission. However, for today's panel let me first say that, to a large extent, I align myself with most of the critical views expressed by the former member and Chair of the Commission, Mr. Alain Pellet, ${ }^{2}$ who served in the Commission for 22 years; his experience

2 Alain Pellet, 'The ILC Adrift? Some Reflections from Inside' in Miha Pogačnik (ed), Challenges of Contemporary International Law and International Relations: Liber Amicorum in Honour of Ernest Petrič (Nova Gorica 2013) 299-312. 
can hardly be ignored. According to him, among the main problems of the Commission in our time are the lack of consideration and respect of States for the work of the Commission, as well as its composition and consequently the problem of its independence, also the independence of its members. They are supposed to be independent experts, but are often government officials. I must say that neither the composition of the Commission nor the independence of its members, after my 12 years on the Commission, seem to be a problem. On the contrary, the combination of academics, diplomats and practitioners seems to be productive, as is the diverse regional background of its membership. I, however, fully share the view of Alain Pellet, who, as the main problem of the contemporary Commission, exposes the selection of topics which are to be dealt with by the Commission and which should lead to codification and progressive development of international law.

I share the view that the lack of profound involvement of States in the selection of topics for the programme of work of the Commission, as well as the insufficient interest and meagre reactions of States throughout the work of the Commission on a topic, is a serious problem. The consequence of this is that practically no drafts produced by the Commission in the last few decades have been transformed into binding international treaties. No codification of international law in the last two decades has been based on the work of the Commission, except perhaps for the Rome Statute of the International Criminal Court. ${ }^{3}$

In my opinion, the problems of the Commission may be summarized as insufficient interest of States for its work, i.e. for the choice of its topics, for its work on a topic and use of its products. Contrary to the present situation, the Commission should in the future be given more guidance by States in the selection of topics and more input by States, including critical feedback, during the work on a topic. It is unfortunate when in most cases less than 30 States react to the Commission's proposal of a topic, or to subsequent reports on the work on it. Not to mention that often there are no reactions at all, or just a few from some regional groups or specific continents, and that many reactions are poorly elaborated, inconcrete and superficial. As a probable consequence of this not very productive relationship between the General Assembly's Sixth Committee and the International Law Commission, when States express their views they are superficially considered and sometimes even ignored in the Commission. To conclude, the relationship between States and the Commission should be more intense, more productive in contributing to the common

3 Adopted 17 July 1998, entered into force 1 July 2002, 2187 UNTS 3. 
task: codification and progressive development of international law. Without improvement of this relationship the Commission might in the future find itself less relevant for States.

Let me add in this context that the decision to hold the first part of the Commission's seventieth session at the United Nations Headquarters in New York was part of the Commission's endeavour to improve the creative relationship between States and the Commission. I have, however, my doubts that this move of the session of the Commission to New York, even if repeated in some future years, will significantly improve the interest of States for the work the Commission and raise awareness among States that the Commission is their organ which should assist them in codifying and developing international law, in fact to establish the rule of law in international relations.

Let me say just a few words concerning the selection of topics in the Commission. According to its still valid statute, the Commission's work has two components: progressive development and codification of international law. ${ }^{4}$ In the work of the Commission, it soon became evident that the division of these two components does not work in practice. In most cases, now as in the past, codification and progressive development go hand in hand, depending on the topic. It will remain so in the future. In most topics both components are present, progressive development and codification. It would be unacceptable and probably impossible in the Commission's drafts to formally distinguish the two and indicate which elements, according to the Commission's view, are supposed to be codification and which elements are progressive development. However, for users of the Commission's products, in particular draft articles that might in the future become binding conventions, it is important to know what the Commission considers already to be existing customary law de lege lata and what might only by a future codification or by future practice of States crystalize from de lege ferenda into binding international law de lege lata. It is thus important that commentaries to proposed drafts indicate what the Commission considers codification of already existing international law de lege lata and what the Commission proposes as progressive development. It is logical to expect that States and other users wish to know what the Commission considers already existing international law and what it only suggests to States as progressive development. The existence or non-existence of relevant and consistent State practice should be crucial in the Commission's consideration and assessment.

It might also be said that in the future work of the Commission on "contemporary" topics, not already covered by abundant State practice, the component

4 Article 1 of the ILC statute. 
of progressive development might grow. In any case, and in line with the statute of the Commission, the General Assembly and its Sixth Committee should have an important, indeed decisive role in the selection of topics if they are indeed to be relevant and thus of interest for States. Not the personal considerations, ambitions, or wishes of members of the Commission - as relevant as they may be - but the needs and proposals of States should be the most relevant in the selection of topics. The Commission is an independent body of experts in international law that serves and helps States in their endeavours to codify and progressively develop international law. The States should, via the General Assembly and its Sixth Committee, submit to the Commission their proposals and recommendations of topics, and the Commission should, according to article 18 of its statute, "give priority to request of the General Assembly to deal with any question." Of course, this assumes that such requests would be made at all. In reality, "requests" from States in the General Assembly and its Sixth Committee very rarely appear. In the majority of cases, the Commission proposes and selects its own topics.

The topics selected by the Commission for its work are supposed to reflect the needs and interest of States. But even when the Commission's proposals of new topics are presented to States, through the Sixth Committee, the reactions of States rarely exceed the level of formal and not much elaborated remarks. Any topic suggested by the Commission is very formalistically endorsed or some reservations to it are expressed. But even in case of reservations of States, the Commission usually proceeds with the topic.

In the last three decades, the General Assembly has not suggested topics for inclusion on the agenda of the Commission and very rarely a State has proposed a topic. There are some exceptions, like in the case of the statute of the International Criminal Court, ${ }^{5}$ which later via negotiations among States became the Rome Statute, establishing the International Criminal Court. It is also worth to mention the suggestion to the Commission of a group of small island States in 2017 to put on its agenda the international legal aspects of rising sea level. ${ }^{6}$ It seems this will soon become a topic of the Commission.

5 See 'Draft Code of Offences against the Peace and Security of Mankind', UnGA Res 36/106 (10 December 1981), para 2; 'International criminal responsibility of individuals and entities engaged in illicit trafficking in narcotic drugs across national frontiers and other transnational criminal activities: establishment of an international criminal court with jurisdiction over such crimes', UNGA Res 44/39 (4 December 1989) para 1.

6 See statement of the Marshall Islands (on behalf of the Pacific Small Island Developing States), made in the Sixth Committee of the General Assembly under agenda item 81, 'Report of the International Law Commission on the work of its sixty-ninth session (Cluster II)' (26 
Since the work of the Commission should first and foremost reflect the needs and wishes of States, additional endeavours should be made to improve the relationship between the Commission and States (i.e. the General Assembly and the Sixth Committee), in particular in the choice of topics to be dealt with by the Commission. It might be useful for this purpose to hold in the Sixth Committee each year, in the framework of the International Law Week, a separate debate focused only on the choice and relevance of future topics of the Commission, those suggested by the Commission and its members and those suggested or preferred by States.

General international law establishes the framework of foreign policy for all States, while it is also being used by States as a means of foreign policy. It is thus important for States what kind of international law is being codified and/ or progressively developed. The future codification and progressive development of international law, and mutatis mutandis of other relevant instruments like "guidelines", "conclusions" and "principles" in the Commission is very important for all States. It is particularly important for those States which might not possess power and other means of foreign policy except international law. They would be expected to be most interested in the future development of international law, its codification and progressive development. It is difficult to understand the passive attitude of many States towards the work of the Commission and to the selection of its topics. I believe that separately organised debate on the Commission's new topics in the Sixth Committee might contribute to more engagement between the Commission and States concerning the development of international law and consequently the rule of law in international community. Also, a special and well-prepared topical and concrete debate in the Sixth Committee on its relationship with the Commission would be useful, whereby revision of the Commission's statute should not a priori be excluded.

There have been critical remarks in the past concerning the choice of some specific topics. Generally, I believe the choice of topics in the Commission has been appropriate, including its work on clarifying important aspects of the law of treaties, which were not sufficiently clarified by the Vienna Convention of $1969^{7}$ (reservations, subsequent practice and subsequent agreement in interpretation of treaties, provisional application of treaties, jus cogens, and also the impact of armed conflicts on treaties). The clarification of those

October 2017) <https://papersmart.unmeetings.org/media2/16154559/marshall-islands-onbehalf-of-pacific-small-island-developing-states-.pdf $>$.

7 Vienna Convention on the Law of Treaties, adopted 23 May 1969, entered into force 27 January 1980, 1155 UNTS 331 . 
important matters of the law of treaties is a great contribution in the last few decades of the Commission to the development and understanding of international law.

In many cases the Commission has opted for the final form of its product not to be draft articles for a future convention, but other forms (guidelines, conclusions principles etc.). In several cases, these forms suit the topic better and also better reflect the development of relevant State practice. Also, the fact that, in the last two decades or more, no draft convention proposed by the Commission was considered by States as capable of becoming a convention probably contributed to preference of other forms of the Commission's products. These guidelines, conclusions and principles can have, and often do have, an important impact on development and interpretation of international law. Often, they might be "stronger" than a non-ratified draft convention not entering into force, which might be a contrario understood as proof that the majority of States does not consider the draft convention to reflect existing international law. States, but also courts and other users of international law may, and often do, in their claims and decisions use the guidelines, conclusions and principles adopted by the Commission as means of proof or as explanation. There seems to be no legal basis for not giving the views of the Commission, even when expressed in non-binding products, similar value and importance as the explanations of decisions of the International Court of Justice and other international courts. Moreover, the role and importance of the Commission, as a subsidiary organ of the General Assembly, entrusted by States to progressively develop and codify international law, should not be equated with private institutions, while important and knowledgeable, like the Institut de Droit international and the International Law Association.

Reflecting on the contemporary development and expansion of international relations, in the future there will be more topics which will require specific, scientific and technical knowledge. The Commission, together with States, will have to find ways to adapt its methodology to handle such topics, for which a general knowledge of international law does not suffice. One can foresee many such topics, since developments of international law in matters such as environmental law, information technology and communications will require it. In the long run, the Commission and States cannot ignore topics that are the result of modern international life and novel needs of the international community. Also, though in the past the ambitious development of international human rights law took part mostly outside the Commission, this does not mean that the Commission should avoid human rights topics. The successful work on the topic of protection of persons in the event of 
disasters is a valuable example. However, in case of human rights topics - and the same is true for topics of international environmental law - the Commission should find a way to involve civil society. This is certainly a difficult and sensitive matter, but also a necessary one, and one that is unavoidable in the contemporary world.

In the past, the Commission has been hesitant to deal with highly political topics. It is true, however, that several topics in the past have had profound political implications, like the responsibility of States (as well as the responsibility of international organizations), topics concerning State succession, the law of the sea, among others. In fact, every topic of international law is ultima ratio also more or less politically relevant. The question, however, is to what extent the Commission, in the future, should avoid "politically sensitive topics" that have important legal connotations and which are now left completely in the hands of States and their political considerations and interpretations. The right of peoples to self-determination, established in the most authoritative international legal instrument, the Charter of the United Nations, and thus a jus cogens norm to some, with all its contradictions, has never attracted the interest of the Commission or States for its interpretation in international law. Questions have been raised, inter alia, regarding its limitations and its relationship to the Charter's principle of sovereign equality of States, as well as regarding the right of States to exist and their territorial integrity to be respected. The question is, who if not the Commission, with its authority, knowledge and mission, should clarify contradictions of this and other similarly important though controversial principles and rules of international law.

In my statement, I have tried to address the questions posed to the panel. I have yet to answer the last: to whom does the Commission speak; only to States or also to courts and other actors? It speaks and should speak first of all to States, and States should speak back to it more. Dialogue between the Commission and States is crucial for both in their common endeavour: the codification and progressive development of international law. It is also clear that the Commission, with its authority, knowledge and wisdom, speaks to courts, international organizations and to all involved and interested in international law. It does so in our times not only through draft articles but also with its several contemporary products, including guidelines, conclusions and principles. Personally, I wish the Commission would, besides to States, speak more to the general public, to all who believe in a future world based on the rule of law. However, its basic role remains helping States to codify and progressively develop international law. It does so as an independent expert body. As an independent expert body in its work, in its conclusions, in its views. But also bound to States to help them, to support them, to listen to their comments, 
and views to serve them. Independence of the Commission from States in its work and in its conclusions is crucial for its successful work and its authority. At the same time, working on topics that are academically interesting but lack relevance to States would not enhance the Commission's independence but could lead to its irrelevance. 